\title{
Invited Review: New Perspectives on the Roles of Nutrition and Metabolic Priorities in the Subfertility of High-Producing Dairy Cows ${ }^{1}$
}

\author{
L. M. Chagas, ${ }^{\star 2}$ J. J. Bass,† D. Blache,‡ C. R. Burke, ${ }^{\star}$ J. K. Kay, ${ }^{\star}$ D. R. Lindsay,‡ M. C. Lucy,§ G. B. Martin,‡ \\ S. Meier, ${ }^{\star}$ F. M. Rhodes,\# J. R. Roche, $\|$ W. W. Thatcher,ף and R. Webb** \\ *Dexcel, Private Bag 3221, Hamilton, New Zealand \\ †Liggins Institute, University of Auckland, Private Bag 92019, Auckland 1003, New Zealand \\ $\ddagger$ The School of Animal Biology, University of Western Australia, 37 Stirling Highway, Crawley, 6009, Australia \\ $\S$ Division of Animal Sciences, University of Missouri, Columbia 65211 \\ \#21 Scotsman Valley Road, Hamilton, New Zealand \\ |University of Tasmania, PO Box 3523, Burnie, Tasmania, Australia 7320 \\ IDepartment of Animal Sciences, University of Florida, Gainesville 32610 \\ **University of Nottingham, Division of Agriculture and Environmental Sciences, School of Biosciences, Loughborough, Leicestershire, \\ LE12 5RD, United Kingdom
}

\section{ABSTRACT}

Management, nutrition, production, and genetics are the main reasons for the decline in fertility in the modern dairy cow. Selection for the single trait of milk production with little consideration for traits associated with reproduction in the modern dairy cow has produced an antagonistic relationship between milk yield and reproductive performance. The outcome is a multifactorial syndrome of subfertility during lactation; thus, to achieve a better understanding and derive a solution, it is necessary to integrate a range of disciplines, including genetics, nutrition, immunology, molecular biology, endocrinology, metabolic and reproductive physiology, and animal welfare. The common theme underlying the process is a link between nutritional and metabolic inputs that support complex interactions between the gonadotropic and somatotropic axes. Multiple hormonal and metabolic signals from the liver, pancreas, muscle, and adipose tissues act on brain centers regulating feed intake, energy balance, and metabolism. Among these signals, glucose, fatty acids, insulin-like growth factor-I, insulin, growth hormone, ghrelin, leptin, and perhaps myostatin appear to play key roles. Many of these factors are affected by changes in the somatotropic axis that are a consequence of, or are needed to support, high milk production. Ovarian tissues also respond directly to metabolic inputs, with consequences for folliculogenesis, steroidogenesis, and

\footnotetext{
Received December 18, 2006.

Accepted May 2, 2007.

${ }^{1}$ Note: This paper was written by the participants of a workshop organized by Lucia M. Chagas of Dexcel Ltd., New Zealand. The other authors are listed alphabetically.

${ }^{2}$ Corresponding author: lucia.chagas@dexcel.co.nz
}

the development of the oocyte and embryo. Little doubt exists that appropriate nutritional management before and after calving is essential for successful reproduction. Changes in body composition are related to the processes that lead to ovulation, estrus, and conception. However, better indicators of body composition and measures of critical metabolites are required to form precise nutritional management guidelines to optimize reproductive outcomes.

The eventual solution to the reduction in fertility will be a new strategic direction for genetic selection that includes fertility-related traits. However, this will take time to be effective, so, in the short term, we need to gain a greater understanding of the interactions between nutrition and fertility to better manage the issue. A greater understanding of the phenomenon will also provide markers for more targeted genetic selection. This review highlights many fruitful directions for research, aimed at the development of strategies for nutritional management of reproduction in the high-producing subfertile dairy cow.

Key words: subfertility, high-producing dairy cow

\section{INTRODUCTION}

Reproductive performance has declined in modern dairy systems concurrently with strong genetic progress for high milk yield (Royal et al., 2002; Berry et al., 2003) and the problem is apparently international among diverse combinations of dairy production systems. Examples include the high-yielding TMR systems typical of North America and the lower yielding pasture-based systems typical of New Zealand, into which cows selected for high production have been introduced (Harris and Kolver, 2001; Lucy, 2003). This suggests 
that reduced fertility is not caused simply by changes in management but also by changes in the genotype and underlying metabolic processes during the genetic progress toward improved potential for productivity (Gutierrez et al., 2006). Moreover, this genetic change does not seem to be the direct cause of low fertility because the problem is not encountered in nulliparous heifers or nonlactating multiparous cows of high-yielding genotypes (Butler and Smith, 1989). These demonstrate that the demands imposed by lactation interact with the genetic makeup of the cow to have a major negative effect on the reproductive system of the modern dairy cow.

High milk yield requires high dietary intake and altered patterns of metabolism, and these outcomes seem to be associated with subfertility (Gutierrez et al., 2006). This review is the product of an international workshop on the relationships among nutrition, metabolic factors, and subfertility and highlights priorities for research into potential solutions.

\section{Declining Fertility}

The decline in fertility in the modern dairy cow probably results from a historical emphasis on selection for milk yield (Berry et al., 2003). This low fertility is related to a multitude of health, physiological, and managerial factors, themselves a result of modifications to a number of physiological processes, including gluconeogenesis, nutrient partitioning, insulin resistance, and appetite signaling (Lucy, 2003). These modifications presumably exist because they offer some advantage to milk production, but they may also prove detrimental to reproductive performance. Many of these issues have arisen because the modern high-producing dairy cow partitions a greater proportion of available nutrients toward milk production at the expenses of body reserves and reproduction (Collard et al., 2000). Consequently, even when nutrient intake is increased to high levels, the outcome is simply an increase in milk production without necessarily an improvement in reproductive performance (Horan et al., 2004).

To improve reproductive function while maintaining high productivity, nutritional strategies are needed that provide regulatory signals to stimulate reproductive processes without compromising the partitioning of energy into milk production. These nutritional strategies will likely vary with cow genotype, dairy production system (e.g., pasture vs. TMR), management system, and their interactions. The development of these strategies must consider the processes that optimize the probability of a successful pregnancy, including early postpartum immune function, uterine health, ovarian function, behavioral estrus, ovulation, and sustaining oviductal and uterine environments to maintain pregnancy and embryonic viability. The complexity of the subfertility syndrome associated with lactation means that developing a solution requires scientific integration of disciplines including animal management, nutrition, immunology, molecular biology, and physiology.

\section{BCS AND NUTRIENT SIGNALS}

The postpartum delay in hyperphagia is associated with body tissue reserves being mobilized to support milk production (Bauman and Currie, 1980). It appears that cows have a physiological target level for body reserves in early lactation (Garnsworthy and Topps, 1982). Therefore, fatter cows at calving will tend to lose more body fat than thinner cows (Garnsworthy, 2007). The relationship between BCS at calving and loss of BCS in early lactation is very strong $\left(\mathrm{r}^{2}=0.82\right)$ and is influenced by genetic merit (Garnsworthy, 2007). The relationship between energy balance and reproductive success is well documented, with BCS at calving and breeding and the duration and severity of the postpartum negative energy balance all reported to influence reproduction (Buckley et al., 2003; Rhodes et al., 2003; Roche et al., 2007). Therefore, management of body reserves is critical for reproductive success and requires an accurate assessment of a cow's "body condition."

Until the 1970s, there was no simple measure of a cow's energy reserves or condition. Body weight alone is a poor indicator because energy stores can vary by as much as $40 \%$ in cows with similar BW (Gibb et al., 1992; Andrew et al., 1994). In addition, because tissues are mobilized in early lactation even though feed intake is generally increasing, the extent of body tissue loss can be masked by gastrointestinal fill, such that BW changes may not reflect changes in bioenergetically important tissues (National Research Council, 2001). Subjective scores of body condition are recommended on dairy farms (Macdonald and Roche, 2004) to overcome the variability of BW. Wright and Russel (1984) reported a strong positive relationship $\left(r^{2}=0.86\right)$ between a subjective visual or tactile (palpation) appraisal of cow condition (i.e., BCS) and the proportion of physically dissected fat in Friesian cows. This finding indicated that the appraisal was a reasonable assessment of body fat reserves, ignoring (or at least minimizing) the influence of frame size and gastrointestinal contents. Furthermore, BCS is easy to measure and practically applicable on farms, enabling large numbers of animals to be assessed quickly, and thereby improving statistical power in experiments and permitting detection of meaningful associations with production and nonproduction traits. Although a number of scoring systems exist globally, they measure the same body areas and 


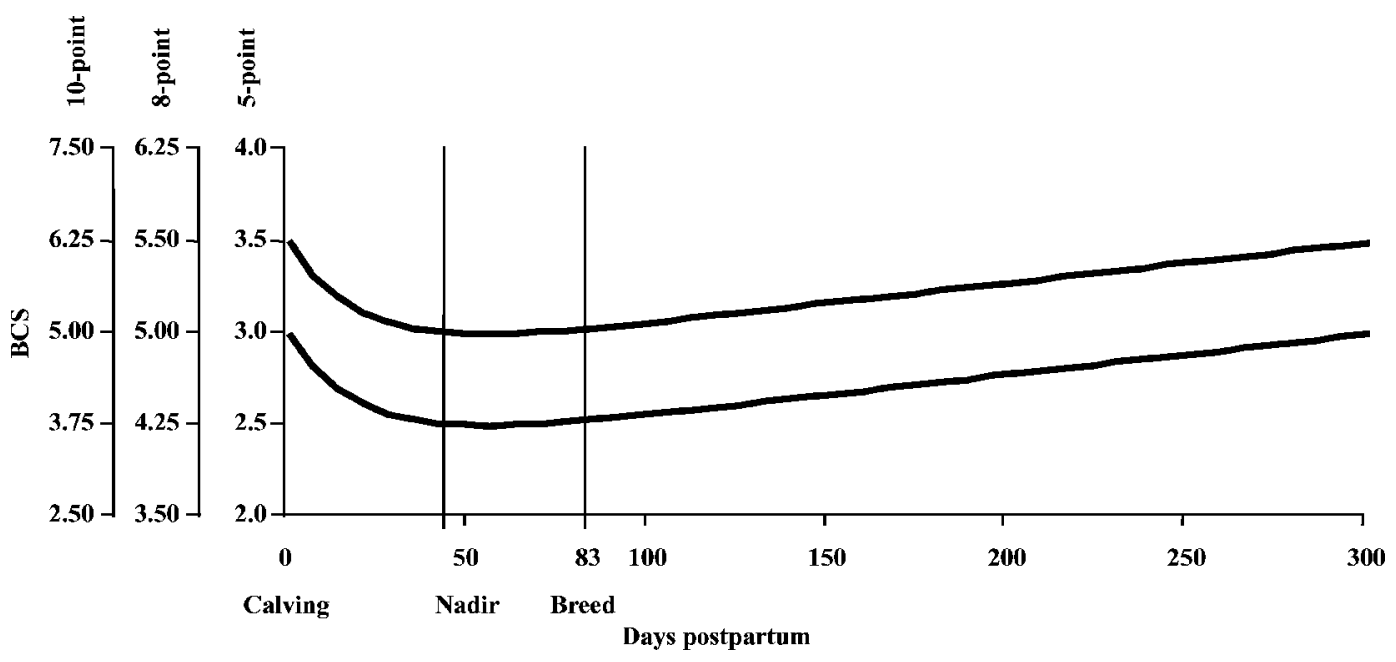

Figure 1. Proposed "ideal body condition score profile" for dairy cows to minimize the effect of energy balance on reproductive failure. Body condition score is presented for the 5-, 8-, and 10-point scales.

are mathematically comparable (Roche et al., 2004), thus allowing international exchange of information. However, the correlation between body condition and body fat probably becomes weak at low BCS where subcutaneous fat content is low, if present at all. The decrease in BCS at these low levels indicates protein loss and not the loss of internal fat depots (Macdonald et al., 1999).

Energy stores during late gestation, calving, and early lactation affect the length of the postpartum anestrus interval (PPAI) and the likelihood of a successful pregnancy (Beam and Butler, 1999; Chagas et al., 2006; Roche et al., 2007). Generally, low BCS at any time in early lactation is associated with delayed ovarian activity, infrequent LH pulses, poor follicular response to gonadotropins, and reduced functional competence of the follicle (characterized by reduced estradiol production; see review by Diskin et al., 2003). A period of postpartum anestrus is normal in the dairy cow; however, when it extends into the breeding season it could result in an increase in reproductive failure.

\section{An Ideal BCS Profile}

Utilizing the BCS system and the published associations among BCS, reproduction, and milk production (Waltner et al., 1993; Buckley et al., 2003; Roche et al., $2007)$, it can be postulated that an "ideal BCS profile" for dairy cows would minimize the impact of negative energy balance on reproductive failure while still allowing cows to achieve high milk production (Figure 1). If such a BCS profile were to be achieved on dairy farms, reproductive performance could be improved. To improve reproductive success, this empirically derived profile must address the key phases where BCS and BCS change have been reported to affect indices of fertility, particularly BCS at calving, BCS change between calving and nadir, BCS at breeding, and BCS or BW change postnadir (Buckley et al., 2003; Roche et al., 2007).

This acceptable profile of BCS change raises 2 immediate questions: 1) why do cows lose BCS after calving and 2) how can the "ideal" BCS profile be achieved? Periparturient changes in energy balance (homeorhesis) dictate that cows will partition nutrients from body reserves to milk production following parturition (Bauman and Currie, 1980). However, the shape of the BCS profile depends on the animal's genetic target BCS, her predisposition to partition nutrients toward milk production and nutrition, and differences between animals in feed conversion efficiency. How these variables affect the profile of BCS change during the transition between parturition and subsequent rebreeding was reviewed recently by Garnsworthy (2007). It is known that genetic selection for production traits results in greater loss of BCS over a longer period postpartum and a failure to repartition significant amounts of energy toward body reserves until later in lactation or when lactation ceases (Roche et al., 2006). This effect is much greater in grazing cows receiving little or no supplementary nonstructural carbohydrates than in TMR-fed cows, probably because of differences in the time taken to recouple the somatotropic axis between the 2 production systems (Roche et al., 2006) and due to differences in blood concentration of insulin, a potent lipogenic agent (Kolver et al., 2006). Consequently, to achieve the ideal BCS profile, it is necessary to better understand the factors that influence nutrient partitioning, 
such as DIM and feed conversion efficiency. It is also necessary to know whether nutritional or management interventions or specific nutrients used at key times can modify the BCS profile.

\section{Limitations of Body Condition Scoring}

An additional problem in ascertaining the importance of energy reserves in reproduction is the failure of BCS to account for changes in internal adipose stores. This cannot be observed externally when evaluating BCS as internal and subcutaneous adipose depots are mobilized and utilized when cows are in negative energy balance (Bauman and Currie, 1980). Although Wright and Russel (1984) reported a strong correlation between BCS and internal energy stores, it is unlikely that they had a sufficiently large sample of cows that would include animals categorized today as "thin" in early lactation. Traditional BCS measures are unlikely to be particularly sensitive when BCS is less than 2.5 (5-point BCS scale; equivalent to 3.75 in the 8-point BCS scale and 4.25 in the 10-point scale; Roche et al., 2004), and there are limited data on the composition of the BCS loss (Grainger et al., 1982; Gibb et al., 1992). Thus, differences in energy stores and changes in energy balance are likely to continue to influence reproduction but the traditional measurement of BCS is less likely to provide worthwhile information about tissue mobilization because cows often have a BCS lower than the visual threshold. In such situations, a cow may be losing more bioenergetically important tissue than is visually apparent, and this tissue might be responsible for metabolic sensory signals that affect reproduction.

In addition, and possibly of greater importance, both BCS and BW only reflect changes retrospectively. The delay in detecting changes in BCS may be after the metabolic effects on reproduction have been initiated. So, an alternative measure of the state of body composition and tissue metabolism is required, one that accounts for changes in protein reserves and internal fat reserves, as well as subcutaneous fat (Kadokawa and Martin, 2006) because the body, under the stress of negative energy balance, mobilizes all these tissues to maintain normal physiological functions.

\section{Specific Nutrients}

Energy balance is not the sole nutritional factor that affects reproduction (Lucy, 2003). Specific nutrients that act independently of energy balance have been reported to directly or indirectly alter reproductive efficiency and fertility. Among these are protein (Armstrong et al., 2001), starch (Armstrong et al., 2001; Burke et al., 2006; Roche et al., 2006), monopropylene glycol (Chagas et al., 2007a), minerals and trace elements (Underwood and Suttle, 2001), and fats (Staples et al., 1998; Boken et al., 2005) including specific lipids such as n-3 fatty acids (Ambrose et al., 2006), rumen inert fats (Staples et al., 1998), and possibly conjugated linoleic acid (Baumgard et al., 2005).

The roles of these nutrients are often complex and experimental results have been inconsistent. For example, of 14 studies examining the effect of supplementary fat on reproductive success, 11 showed a positive effect and 3 showed a negative effect (see review by Staples et al., 1998). Similarly, the inclusion of dietary starch can shorten the duration of negative energy balance, thereby increasing nadir BCS, postnadir BW gain, and the level of circulating IGF-I, and shortening PPAI, potentially enhancing reproductive success (Burke et al., 2006; Kolver et al., 2006; Roche et al., 2006). However, starch supplements are also reported to reduce oocyte quality (Armstrong et al., 2001), and if so, they would negate any of the potential benefits from improved energy balance and reduced PPAI. Similarly, the effects of protein and its metabolites are unclear. Both Sinclair et al. (2000) and Armstrong et al. (2001) reported a reduction in oocyte quality when dietary protein was increased, consistent with the reduction in conception rate with increased RDP (Canfield et al., 1990). Nevertheless, in pasture-based production systems, where the availability of RDP can be twice as much as required, conception rates are generally better than those seen in systems in which balanced diets are offered (Royal et al., 2000; Harris, 2005). However, it is unlikely that any of these specific dietary components will provide simple solutions to the problem of subfertility associated with lactation in high-yielding dairy cows. Further research is required to better understand the effect of these individual nutrients and the interactions among different nutrients on reproductive success. Identification of selective functional nutrients that could be targeted through the diet is probably necessary to optimize the diet for the stages in the temporal sequence of the reproductive process, such as postpartum health, uterine regression, resumption of estrus cycles, and embryo survival.

\section{METABOLIC SIGNALS AND REPRODUCTION}

Links exist between metabolic maintenance and reproductive efficiencies that involve the complex integration of endocrine and metabolic signals controlling metabolism and reproduction. Whatever the mechanism, it is clear that the reproductive success of the dairy cow is linked to body energy reserves and metabolic responses to nutrition (Roche, 2006). These responses must inevitably involve signaling molecules and hor- 


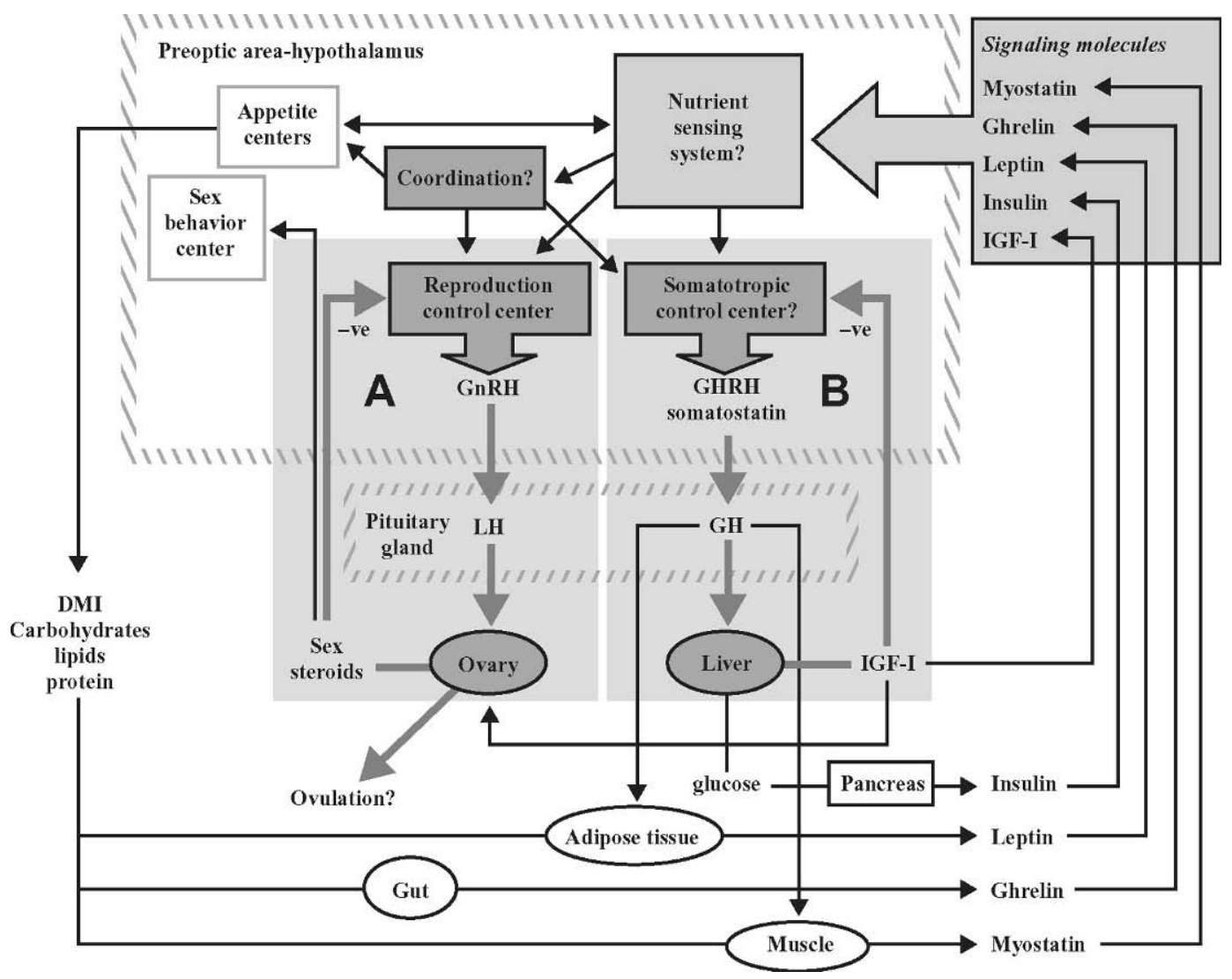

Figure 2. The feedback-regulated systems that control the reproductive axis (shaded area A) and the somatotropic axis (shaded area B) interact at several levels and thus link nutritional and metabolic inputs into the reproductive process. Note that for the reproductive axis, FSH is omitted because it does not appear to limit dairy cow fertility. In addition, for the sake of clarity, the thyroid and adrenocortical axes have been omitted: they are both regulated by their own feedback loops in the brain-pituitary system, both are intimately linked with lactation, both respond to metabolic inputs, and both affect the reproductive and somatotropic systems, so they introduce inputs from stressors such as high ambient temperature, disease, and the antagonistic interactions associated with establishment of social dominance. With respect to sex-steroid feedback, positive feedback for induction of the preovulatory surge has been omitted.

mones that are integral components of the control systems that regulate the partitioning of energy and nutrients and the reproductive axis (Figure 2).

When they are identified, these signaling molecules will be produced by the many sites (organs) that are involved in processing, storage, and utilization of nutrients, or in the reproductive process. Moreover, to ensure precise regulation of energy and protein partitioning, and integration with the reproductive process, any given signal probably interacts with other signal(s). It is likely that the main systems involved in these regulatory and integrative functions are in and around the hypothalamic-preoptic area, in locations close to the GnRH neurons (Blache et al., 2006, 2007; Figure 2).

\section{The Brain}

The preoptic-hypothalamic continuum is involved in the integration of appetite (Wynne et al., 2005), estrus behavior (Pfaff, 2005), and nutritional sensing (Wade and Jones, 2004), and produces the releasing hormones that control the secretion of gonadotropins and somatotropin (Kacsoh, 2000). The gonadotropic system is the key driver of reproduction, whereas the somatotropic system is the key driver of milk production, lipolysis, and tissue maintenance (Baile and Buonomo, 1987; Okamura and Ohkura, 2007). Inputs to the hypothalamic regulatory sites may have divergent effects on the gonadotropic and somatotropic pathways, such that stimulation of growth hormone $(\mathbf{G H})$ production may be associated with the inhibition of $\mathrm{GnRH}$ release (Zieba et al., 2005).

The hormonal pathways that send signals from the peripheral organs to the brain, and the neuropeptidergic pathways that link the neurons sensitive to peripheral hormones to the GnRH neurons have been major topics of research, but the roles of each system are still poorly understood (Blache et al., 2006). However, the 
systems linking reproduction to feed intake and metabolism are critical for an understanding of an integrated system. The importance of some hormonal systems, such as IGF-I, insulin, and, potentially, leptin, is strongly supported by research in dairy cattle (Gong et al., 2002; Diskin et al., 2003). However, the integration of hormones such as adiponectin and ghrelin linking nutrition and reproduction (Tena-Sempere, 2005) has not been studied intensively in dairy cattle.

In addition to these integrative and regulatory systems in the preoptic-hypothalamic continuum, extrahypothalamic pathways appear to be involved. Noradrenergic afferents from the brainstem may play a role, as leptin receptors have been localized in this region and noradrenergic fibers project into the preoptic area (Rawson et al., 2001). Furthermore, time is an additional dimension because the brain's responses to nutrients and hormones can involve delays and can vary with season (Blache et al., 2007). It is necessary to study the bovine brain to determine its sensitivity to peripheral hormones and the nature of its neural pathways to understand what is happening in the subfertile dairy cow.

In addition to neural communication between the brain and extracranial tissues, there are neural connections that allow information to flow to and from the brain via the autonomic nervous system (e.g., the communication between adipose tissue and the brain; Bartness et al., 2005). The biological significance of this has not been determined to date for any animal model, let alone the high-producing subfertile dairy cow.

\section{Somatic Tissue}

Tissues other than the brain, including liver, fat, and muscle, also link metabolism and reproduction through the production of several metabolites and hormones. The importance of $\mathrm{GH}$ as a principal coordinator of these activities in the high-producing dairy cow cannot be overstated (Lucy, 2003). In addition to directly stimulating liver, muscle, and fat to release metabolites such as glucose and NEFA, GH acts on the liver and other organs, such as the pancreas and gut, to promote the release of several hormones and metabolites including IGF-I, insulin, ghrelin, and leptin that feed back to the centers controlling appetite and reproduction, as well as acting directly on the mammary gland and reproductive tract. Increased GH and NEFA antagonize insulin action and create a state of insulin resistance in postpartum cows (Lucy, 2007). Insulin resistance reduces the uptake of glucose by extramammary tissues with insulin-dependent glucose transporters, thereby conserving glucose for milk synthesis. Insulin and IGFI act directly on the ovary (to increase the sensitivity of the ovary to LH and FSH) as well as on the uterus and embryo (Watson et al., 1999; Webb et al., 2004; Bilby et al., 2006). Therefore, insulin and IGF-I may be responsible for mediating an effect of body condition on the uterus and embryo, as well as on ovarian follicle development and ovulation. This is a very clear example of how focused selection for high milk yield may have produced detrimental side effects on reproduction.

Growth hormone may also affect reproductive processes through its effect on muscle metabolism. Skeletal muscle can be regarded as a single "organ" in the body and, because it is very large, its requirements for maintenance and metabolism during peak periods of energy demand (i.e., postpartum) are likely to affect the energy and protein available for reproduction. Muscle, like many other tissues, not only responds to endocrine inputs, but also produces hormones, as well as local (paracrine) factors, that are important for integrating the activity of muscle tissues with other systems in the body. For example, muscle has GH receptors, so somatotropin is involved directly in maintenance of myofibers and affects muscle tissue indirectly by enhancing local production of IGF-I (Sotiropoulos et al., 2006). Muscle atrophy, resulting from low energy availability, is due to the production of myostatin, a member of the transforming growth factor- $\beta$ superfamily (Lee, 2004). Myostatin directly promotes muscle atrophy by increasing the mobilization of muscle proteins, making them available for other tissues (Zimmers et al., 2002). Circulating myostatin has also been shown to play a role in controlling plasma glucose by down-regulating the insulindependent glucose transporter, Glut4, which increases the insulin resistance of both muscle and fat (Strassman et al., 2002). Myostatin also plays a role in fetal growth by decreasing glucose uptake in early placental tissue but increasing uptake late in pregnancy (Mitchell et al., 2006). The regulatory consequences of uterine involution (i.e., turnover of smooth muscle) on the metabolic processes of nutrient partitioning and restoration of gonadotropin secretion during the period of negative energy balance have not been studied extensively. Thus, the importance of muscle cannot be underestimated in assessing the metabolic status of lactating dairy cows because it plays major metabolic and endocrine roles during times of negative energy balance. It might directly affect reproduction by competing for scarce nutrients and by exerting endocrine effects such as the action of myostatin on the insulin-glucose axis.

\section{Appetite and Metabolism}

Increased intakes and metabolic rates typical of early lactation result in greater breakdown and clearance of both estradiol and progesterone (Wiltbank et al., 2006), 
thus modifying their feedback effects. Folliculogenesis is reduced because of the impact of feed intake on the reproductive axis, resulting from a reduction in circulating steroids. The result is that the high-producing cow has low plasma estradiol concentrations, so reducing stimulation of the centers that control estrous behavior (Lopez et al., 2004) and possibly the release of the LH surge that induce ovulation. Reduced circulating concentrations of progesterone are associated with reduced pregnancy rates (McNeill et al., 2006).

In contrast, factors controlling appetite, and thus nutrient intake, are critically important. As nutrients are processed through the gastrointestinal tract, a number of hormones and metabolites are released and feed back to the hypothalamus and to GH-responsive tissues such as liver, muscle, and fat. Thus, when appetite is depressed or intake is limited, more GH is released and the reproductive-endocrine axis is suppressed. Some of these responses are probably mediated by decreased ghrelin secretion by the abomasum in response to an increased intake. Lower concentrations of ghrelin allow an increase in the activity of the reproductive centers in the brain, perhaps via its effect on $\mathrm{GH}$ secretion (see review by Tena-Sempere, 2005; Figure 2). Any factor that affects intake and appetite in the periparturient dairy cow will bring these mechanisms into play. This applies to diseases such as metritis and mastitis. In addition, environmental factors such as cold/heat stress and social interactions such as dominance and sexual behavior can also reduce the activity of the reproductive axis, due to their effect on feed intake.

During the periparturient period, when cows are usually in severe negative energy balance and blood concentrations of several nutrients are reduced, the immune system is strongly suppressed. Consequently, high-producing cows are more susceptible than normal to infectious diseases such as metritis and mastitis (Lyons et al., 1991), which affects reproduction. It does appear that the metabolic challenges associated with the onset of lactation and marked turnover on uterine tissue can affect immune function (Goff, 2006). Neutrophil function declines in both intact and mastectomized cows as parturition approaches but rebounds much faster in mastectomized cows than in lactating cows (Goff, 2006) indicating that milk production might be indirectly associated with loss of immunocompetence.

\section{Direct Communication with Reproductive Organs}

As described in Figure 2, the reproductive system is controlled primarily by the central nervous system, but there is also potential for direct metabolic input into the ovary, uterus, and conceptus. "Cross-talk" between the systems that control reproduction and lacta- tion (i.e., lactogenesis and early galactopoiesis) influences ovulation, expression of estrus, corpus luteum function, and maintenance of pregnancy (McNeilly, 2001; Lamote et al., 2004). Much of this cross-talk involves multiple actions by $\mathrm{GH}$ in a number of tissues and helps to explain some of the subfertility of the highproducing dairy cow. This possibility is supported by studies in vivo and in vitro (Gong et al., 1991; FouladiNashta and Campbell, 2006).

In vivo studies on the ovary, oviduct, and uterus of cows reported that the corpus luteum, follicles, uterus, and conceptus respond to exogenous GH (Gong et al., 1991). Within the follicles, locally produced IGF-II and circulating IGF-I influence the responses of the theca and granulosa cells to gonadotropins. The availability of the 2 IGFs to these cells is controlled by locally produced IGF-binding proteins (IGFBP; Webb et al., 2003, 2004; Spicer et al., 2004). The expression of mRNA for IGFBP2 and IGFBP-4 in small antral follicles is altered by changes in diet, which has been shown to affect follicle development (Armstrong et al., 2003). Importantly, antral follicles respond to dietary manipulation in the absence of an alteration in circulating patterns of the gonadotropins. Instead, the follicular responses are correlated with changes in peripheral concentrations of metabolic hormones including GH, insulin, IGF-I, and leptin. These effects may also be induced by changes in circulating metabolites including fatty acids, amino acids, and glucose (Webb et al., 2003, 2004). In addition, exogenous GH stimulates development of the conceptus on 17 after insemination, and exposure of the endometrium to the conceptus alters its responsiveness to $\mathrm{GH}$, increasing expression of IGF-II mRNA (Bilby et al., 2006).

These observations are supported by in vitro studies that can be interpreted more confidently following the development of culture systems that retain the normal functions of theca and granulosa cells (see review by Webb et al., 2003, 2004). It is clear that the function of follicular cells can be modified by locally produced growth factors, such as IGF-II (Gutierrez et al., 1997, 2000; Spicer et al., 2004), and by metabolic hormones from the circulation, such as insulin, IGF-I, and leptin (Sinclair and Webb, 2005). Circulating concentrations of insulin are affected by diet and the changes are positively correlated with changes in estradiol produced by granulosa cells from small (1 to $4 \mathrm{~mm}$ ) antral follicles (Armstrong et al., 2002). Furthermore, the addition of insulin to larger bovine follicles $(>4 \mathrm{~mm}$ ) eliminates IGFBP-2 and IGFBP-5 in the follicular fluid (FouladiNashta and Campbell, 2006).

These observations on the direct responses of the bovine ovary to metabolic factors could perhaps be explained by following new directions as indicated by 
work in other species. For example, leptin affects reproduction in mice and modulates steroid production by cultured ovarian somatic cells in a number of species, including cattle (Spicer and Francisco, 1998). A direct role of leptin on ovarian function in vivo has been demonstrated in sheep. For example, passive immunization against leptin acutely increases ovarian estradiol secretion, whereas infusion of leptin directly into the ovary results in an acute, dose-dependent decline in estradiol secretion (Kendall et al., 2004). Together, these observations provide strong evidence that leptin can modulate ovarian steroidogenesis directly and acutely in ruminants. They also suggest that leptin is an alternative regulatory system through which nutritional status can regulate reproductive activity.

In addition to the immediate and direct responses of ovarian follicles to metabolic inputs, there are delayed effects on the oocyte that become apparent as the conceptus develops. Thus, the effects of diet on IGFBP in follicular fluid, along with changes in caspase-3 activity, can be linked to the developmental competence of the oocyte (Adamiak et al., 2005, 2006; Nicholas et al., 2005). In the high-yielding dairy cow, supplementary dietary carbohydrates can reduce the quality of oocytes and the development of embryos, resulting in fewer blastocyst cells and a lower rate of blastocyst production (Fouladi-Nashta et al., 2005). It is necessary to know how the metabolic input reaches the oocyte so that nutritional strategies can be developed to improve the quality of the oocytes in the high-producing subfertile dairy cow.

In summary, the evidence is overwhelming that the ovary has some degree of independence from gonadotropic drive and can respond directly to metabolic inputs, particularly those affected by the commitment of modern dairy cows to high milk production in the early postpartum period.

\section{Temporal Interactions with Metabolic Inputs and Fertility}

Time delays are a natural aspect of the processes regulating follicular development in the cow because a follicle emerging from the primordial pool takes 4 to 5 mo to reach the ovulatory phase (Webb et al., 2003). Therefore, nutritional management in the period leading up to parturition, in combination with gestational hormone patterns during that period, can have consequences for fertility throughout the subsequent lactation. This has been clearly demonstrated in first-calving heifers, arguably the animal in the dairy production system that is most sensitive to nutritional inputs (Burke et al., 1995). In these animals, dynamic changes in BCS during the 6 wk before calving can have signifi- cant effects on the PPAI. Heifers with a low BCS at 6 wk prepartum, when offered unrestricted pasture, had a shorter PPAI and increased pulsatile release of $\mathrm{LH}$ in early lactation compared with animals that were maintained on restricted intakes for the final $6 \mathrm{wk}$ of pregnancy, but equivalent to animals that were well fed throughout pregnancy (Chagas et al., 2006). In that study, all the animals received unrestricted pasture following calving. In contrast, in heifers calving in good body condition, PPAI did not differ between animals on different levels of pasture following calving (Chagas et al., 2007b). Thus, prepartum nutrition and peripartum body condition have major effects on PPAI that are not reversed by postpartum energy intakes. Presumably, this is mediated by the somatotropic and gonadotropic axes but the mechanisms are not clear from the patterns in plasma concentrations of glucose, NEFA, insulin, IGF-I, GH, or leptin, which differed little between treatments (Chagas et al., 2006). These observations suggest the existence of a type of "metabolic memory," through which prepartum nutrition determines the response of the heifers to their postpartum energy supply and ultimately controls the secretion of $\mathrm{GnRH}$ and consequently, PPAI. Similar observations by Burke et al. $(2005,2006)$ in multiparous cows support this hypothesis.

Oocyte quality is also affected by an interaction between feeding level and body condition: a high level of feeding is beneficial to oocytes from animals of low body condition, but detrimental to oocytes from animals of moderate to high body condition (Adamiak et al., 2005). Furthermore, this interaction is cumulative over a 3mo period, with blastocyst yields from fat heifers on a high diet (twice maintenance) deteriorating with time relative to thinner heifers on the same high diet (Adamiak et al., 2005). Thus, metabolic and dietary factors appear to influence the oocytes of preantral follicles, although this needs to be confirmed and the mechanisms elucidated.

A longer-term delayed effect on the reproductive axis is suggested by observations in sheep, where undernutrition during gestation affects the development of ovarian follicles in female fetuses (Borwick et al., 1997; Rae et al., 2001) and reduces lifetime reproductive performance (Rhind et al., 1998). Thus, problems with energy balance, nutrition, and metabolic disturbance in dairy cows before and during early pregnancy might (as seen in sheep) result in detrimental effects on ovarian development in the female fetus.

Conceivably, this might explain some of the infertility in high-yielding herds. Programming of the metabolic control systems in the developing fetus might also affect the way that cows respond to the challenge of milk production; for example, by changing the balance of 
the GH-IGF-I system (Augustin et al., 2003). Further investigation is required to determine whether fetal sensitivity/response to the demands of lactation or dietary inputs of high-producing cows have long-term effects on hypothalamic, ovarian, and uterine tissues, which may impair future reproductive competence.

In summary, there are several clear examples of timedelayed consequences for fertility in the relationship between the lactogenic and gonadotropic control systems in the high-producing subfertile dairy cow. Further study is necessary to understand the processes involved and to determine whether there are opportunities for application at the industry level. For example, is metabolic memory with its time-delayed effects as important in multiparous cows as it seems to be in heifers? Recent evidence indicates that it may be (Burke et al., 2005, 2006).

Overall, the interaction between availability of nutrients and sensitivity to metabolic inputs determines the outcome of pregnancy through direct actions on the reproductive tissues as well as through the control systems outlined in Figure 2. The nutritional requirements and metabolic signals that are critical for each of the key developmental stages, from initiation of follicular development to the implantation of the fetus, as well as intergenerational effects, are still to be identified. The impact of genotype on reproductive responses to diet is also unknown. The outcomes of research in these areas will provide information for the formulation of nutritional strategies and diets that meet the requirements of the high-producing subfertile dairy cow during transitional and postpartum periods.

\section{CONCLUSIONS}

The subfertility of the high-producing dairy cow is, in part, the result of intensive selection for milk production traits and intensification of management systems with little consideration for the resulting impact on reproduction. The consequence of this is an apparent conflict between milk production and fertility. This conflict is not inevitable because traits for fertility can be included successfully in selection indices (Flint et al., 2004), as has been demonstrated in Scandinavia, where milk production has been improved without compromising reproduction (Philipsson and Lindé, 2003). If there were to be a genetic solution for the high-producing, subfertile dairy cow, reproductive traits would have to become a significant component of the selection index. Alternatively, it may be feasible to select for more persistent lactation or smaller postpartum changes in BCS to improve fertility. It is important to recognize that a single genotype is not appropriate for all production systems because environment, management systems, and profit drivers vary greatly from one country to another. The genetic solution will require decades to achieve its objective. In this review, fruitful directions for research have been suggested, which could lead to the development of nutritional management strategies to provide means for optimized milk production without compromising fertility across diverse dairy systems.

\section{ACKNOWLEDGMENTS}

This workshop was funded by the New Zealand Foundation for Science, Research and Technology. Thanks go to Werner Hennig for the dedication he put into the catering for the workshop team.

\section{REFERENCES}

Adamiak, S. J., K. Mackie, R. G. Watt, R. Webb, and K. D. Sinclair. 2005. Impact of nutrition on oocyte quality: Cumulative effects of body composition and diet leading to hyperinsulinaemia in cattle. Biol. Reprod. 73:918-926.

Adamiak, S. J., K. Powell, J. A. Rooke, R. Webb, and K. D. Sinclair. 2006. Body composition, dietary carbohydrates and fatty acids determine post-fertilisation development of bovine oocytes in vitro. Reproduction 131:247-258.

Ambrose, D. J., J. P. Kastelic, R. Corbett, P. A. Pitney, H. V. Petit, J. A. Small, and P. Zalkovic. 2006. Lower pregnancy losses in lactating dairy cows fed a diet enriched in alpha-linolenic acid. J. Dairy Sci. 89:3066-3074.

Andrew, S. M., D. R. Waldo, and R. A. Erdman. 1994. Direct analysis of body composition of dairy cows at three physiological stages. J. Dairy Sci. 77:3022-3033.

Armstrong, D. G., J. G. Gong, J. O. Gardner, G. Baxter, C. O. Hogg, and R. Webb. 2002. Steroidogenesis in bovine granulosa cells: The effect of short-term changes in dietary intake. Reproduction 123:371-378.

Armstrong, D. G., J. G. Gong, and R. Webb. 2003. Interactions between nutrition and ovarian activity in cattle: Physiological, cellular and molecular mechanisms. Reprod. Suppl. 61:403-414.

Armstrong, D. G., T. G. McEvoy, G. Baxter, J. J. Robinson, C. O. Hogg, K. J. Woad, R. Webb, and S. D. Sinclair. 2001. Effect of dietary energy and protein on bovine follicular dynamics and embryo production in vitro: Associations with the ovarian insulinlike growth factor system. Biol. Reprod. 64:1624-1632.

Augustin, R., P. Pocar, C. Wrenzycki, H. Niemann, and B. Fischer. 2003. Mitogenic and anti-apoptotic activity of insulin on bovine embryos produced in vitro. Reproduction 126:91-99.

Baile, C. A., and F. C. Buonomo. 1987. Growth hormone-releasing factor effects on pituitary function, growth, and lactation. J. Dairy Sci. 70:467-473.

Bartness, T. J., C. Kay Song, H. Shi, R. R. Bowers, and M. T. Foster. 2005. Brain-adipose tissue cross talk. Proc. Nutr. Soc. 64:53-64.

Bauman, D. E., and W. B. Currie. 1980. Partitioning of nutrients during pregnancy and lactation: A review of mechanisms involving homeostasis and homeorhesis. J. Dairy Sci. 63:1514-1529.

Baumgard, L. H., J. K. Kay, C. E. Moore, J. R. Roche, M. J. VanBaale, and R. P. Rhoads. 2005. Regulating milk fat synthesis: Potential on-farm applications of basic science. Proc. N.Z. Soc. Anim. Prod. 65:33-39.

Beam, S. W., and W. R. Butler. 1999. Effects of energy balance on follicular development and first ovulation in postpartum dairy cows. J. Reprod. Fertil. Suppl. 54:411-424.

Berry, D. P., F. Buckley, P. Dillon, R. D. Evans, M. Rath, and R. F. Veerkamp. 2003. Genetic relationships among body condition score, body weight, milk yield, and fertility in dairy cows. J. Dairy Sci. 86:2193-2204. 
Bilby, T. R., A. Sozzi, M. M. Lopez, F. T. Silvestre, A. D. Ealy, C. R. Staples, and W. W. Thatcher. 2006. Pregnancy, bovine somatotropin, and dietary n-3 fatty acids in lactating dairy cows: I. Ovarian, conceptus, and growth hormone-insulin-like growth factor system responses. J. Dairy Sci. 89:3360-3374.

Blache, D., L. M. Chagas, and G. B. Martin. 2007. Nutritional inputs into the reproductive neuroendocrine control system-A multidimensional perspective. Reprod. Suppl. 64:124-139.

Blache, D., S. Zhang, and G. B. Martin. 2006. Dynamic and integrative aspects of the regulation of reproduction by metabolic status in male sheep. Reprod. Nutr. Dev. 46:379-390.

Boken, S. L., C. R. Staples, L. E. Sollenberger, T. C. Jenkins, and W. W. Thatcher. 2005. Effect of grazing and fat supplementation on production and reproduction of Holstein cows. J. Dairy Sci. 88:4258-4272.

Borwick, S. C., S. M. Rhind, S. R. McMillen, and P. A. Racey. 1997. Effect of undernutrition of ewes from the time of mating on fetal ovarian development in mid gestation. Reprod. Fertil. Dev. 9:711-715

Buckley, F., K. O'Sullivan, J. F. Mee, R. D. Evans, and P. Dillon. 2003. Relationship among milk yield, body condition, cow weight and reproduction in spring-calved Holstein-Friesians. J. Dairy Sci. 86:2308-2319

Burke, C. R., S. McDougall, and K. L. Macmillan. 1995. Effects of breed and calving live weight on postpartum ovarian activity in pasture-fed dairy heifers. Proc. N.Z. Soc. Anim. Prod. 55:76-78.

Burke, C. R., J. R. Roche, P. W. Aspin, and J. M. Lee. 2006. A nutrientsignalling effect of grain feeding on postpartum anovulatory intervals in matture dairy cows. Proc. N.Z. Soc. Anim. Prod. 66:334-338.

Burke, C. R., J. R. Roche, P. W. Aspin, J. M. Lee, and V. K. Taufa. 2005. Effect of pre- and postpartum pasture feeding intakes on postpartum anoestrous intervals in dairy cows. Proc. N.Z. Soc. Anim. Prod. 65:221-224.

Butler, W. R., and R. D. Smith. 1989. Interrelationships between energy balance and postpartum reproductive function in dairy cows. J. Dairy Sci. 72:767-783.

Canfield, R. W., C. J. Sniffen, and W. R. Butler. 1990. Effects of excess degradable protein on postpartum reproduction and energy balance in dairy cattle. J. Dairy Sci. 73:2342-2349.

Chagas, L. M., P. J. S. Gore, S. Meier, K. A. Macdonald, and G. A. Verkerk. 2007a. Effect of mono propylene glycol on luteinizing hormone, metabolites and postpartum anovulatory intervals in dairy heifers. J. Dairy Sci. 90:1168-1175.

Chagas, L. M., P. J. S. Gore, G. A. Verkerk, K. A. Macdonald, and D. Blache. 2007b. Restricted postpartum feeding in grazing dairy heifers decreases milk production but does not lengthen anoestrous interval. Proc. N.Z. Soc. Anim. Prod. 67:255-260.

Chagas, L. M., F. M. Rhodes, D. Blache, P. J. S. Gore, K. A. Macdonald, and G. A. Verkerk. 2006. Precalving feeding and body condition effects on metabolic responses and postpartum anestrus interval in grazing primiparous dairy cows. J. Dairy Sci. 89:1981-1989.

Collard, B. L., P. J. Boettcher, J. C. Dekkers, D. Petitclerc, and L. R. Schaeffer. 2000. Relationships between energy balance and health traits of dairy cattle in early lactation. J. Dairy Sci. 83:2683-2690

Diskin, M. G., D. R. Mackey, J. F. Roche, and J. M. Sreenan. 2003. Effects of nutrition and metabolic status on circulating hormones and ovarian follicle development in cattle. Anim. Reprod. Sci. $78: 345-370$

Flint, A. P. F., S. Brotherstone, M. P. Coffey, M. D. Royal, J. Santarossa, G. Simm, A. Stott, E. Wall, and J. A. Woolliams. 2004 The UK Fertility Index. Pages 59-62 in Proc. British Cattle Conference. The British Cattle Breeders Club, ed. British Cattle Breeders Club, Devon, UK.

Fouladi-Nashta, A. A., and K. H. Campbell. 2006. Dissociation of oocyte nuclear and cytoplasmic maturation by the addition of insulin in cultured bovine antral follicles. Reproduction 131:449-460.

Fouladi-Nashta, A. A., C. G. Gutierrez, P. C. Garnsworthy, and R. Webb. 2005. Effects of dietary carbohydrate source on oocyte/ embryo quality and development in high yielding lactating dairy cattle. Biol. Reprod. 70 Special Edition 1: Abstr. 244.

Garnsworthy, P. C. 2007. Body condition score in dairy cows: Targets for production and fertility. Pages $61-86$ in Recent Advances in Animal Nutrition 2006. P. C. Garnsworthy and J. Wiseman, ed. Nottingham University Press, Nottingham, UK.

Garnsworthy, P. C., and J. H. Topps. 1982. The effect of body condition score at calving on their food intake and performance when given complete diets. Anim. Prod. 35:113-119.

Gibb, M. J., W. E. Ivings, M. S. Dhanoa, and J. D. Sutton. 1992. Changes in body components of autumn-calving HolsteinFriesian cows over the first 29 weeks of lactation. Anim. Prod. 55:339-360.

Goff, J. P. 2006. Major advances in our understanding of nutritional influences on bovine health. J. Dairy Sci. 89:1292-1301.

Gong, J. G., T. Bramley, and R. Webb. 1991. The effect of recombinant bovine somatotropin on ovarian function in heifers: Follicular populations and peripheral hormones. Biol. Reprod. 45:941-949.

Gong, J. G., W. J. Lee, P. C. Garnsworthy, and R. Webb. 2002. Effect of dietary-induced increases in circulating insulin concentrations during the early postpartum period on reproductive function in dairy cows. Reproduction 123:419-427.

Grainger, C., G. D. Wilhems, and A. A. McGowan. 1982. Effects of body condition at calving and the level of feeding in early lactation on milk production of dairy cows. Aust. J. Exp. Agric. Anim. Husb. 22:9-17.

Gutierrez, C. G., B. K. Campbell, and R. Webb. 1997. Development of a long-term bovine granulosa cell culture system: Induction and maintenance of estradiol production, response to follicle-stimulating hormone, and morphological characteristics. Biol. Reprod. 56:608-616.

Gutierrez, C. G., J. G. Gong, T. A. Bramley, and R. Webb. 2006. Selection on the predicted breeding value for milk production delays ovulation independently of changes in follicular development, milk production and body weight. Anim. Reprod. Sci. 95:193-205.

Gutierrez, C. G., J. H. Ralph, E. E. Telfer, I. Wilmut, and R. Webb. 2000. Growth and antrum formation of bovine preantral follicles in long-term culture in vitro. Biol. Reprod. 62:1322-1328.

Harris, B. L. 2005. Multiple trail fertility model for the national genetic evaluation. Livestock Improvement Corporation. 1-24. www.aeu.org.nz/page.cfm?id=59\&nid=35

Harris, B. L., and E. S. Kolver. 2001. Review of holsteinization on intensive pastoral dairy farming in New Zealand. J. Dairy Sci. 84(E Suppl.):E56-E61.

Horan, B., J. F. Mee, M. Rath, P. O'Connor, and P. Dillon. 2004. The effect of strain of Holstein-Friesian cow and feeding system on reproductive performance in seasonal-calving milk production systems. Anim. Sci. 79:453-468.

Kacsoh, B. 2000. Endocrine Physiology. McGraw Hill Book Co., New York, NY.

Kadokawa, H., and G. B. Martin. 2006. A new perspective on management of reproduction in dairy cows: The need for detailed metabolic information, an improved selection index and extended lactation. J. Reprod. Dev. 52:161-168.

Kendall, N. R., C. G. Gutierrez, R. J. Scaramuzzi, D. T. Baird, R. Webb, and B. K. Campbell. 2004. Direct in vivo effects of leptin on ovarian steroidogenesis in sheep. Reproduction 128:757-765.

Kolver, E. S., J. R. Roche, and P. W. Aspin. 2006. Plasma insulin, growth hormone and IGF-1 concentrations of Holstein-Friesian Cows of divergent genotype offered varying level of concentrate in early lactation. Proc. N.Z. Soc. Anim. Prod. 66:403-408.

Lamote, I., E. Meyer, A. M. Massart-Leen, and C. Burvenich. 2004. Sex steroids and growth factors in the regulation of mammary gland proliferation, differentiation, and involution. Steroids 69:145-159.

Lee, S. J. 2004. Regulation of muscle mass by myostatin. Annu. Rev. Cell Dev. Biol. 20:61-86.

Lopez, H., L. D. Satter, and M. C. Wiltbank. 2004. Relationship between level of milk production and estrous behavior of lactating dairy cows. Anim. Reprod. Sci. 81:209-223. 
Lucy, M. C. 2003. Mechanisms linking nutrition and reproduction in postpartum cows. Reproduction 61:415-427.

Lucy, M. C. 2007. Fertility in high-producing dairy cows: Reasons for decline and corrective strategies for sustainable improvement. Reprod. Suppl. 64:237-254.

Lyons, D. T., A. E. Freeman, and A. L. Kuck. 1991. Genetics of health traits in Holstein cattle. J. Dairy Sci. 74:1092-1100.

Macdonald, K. A., and J. Roche. 2004. Condition scoring made easy. Pages 4-7 in Condition Scoring Dairy Herds. Dexcel Ltd., Hamilton, New Zealand.

Macdonald, K. A., G. A. Verkerk, and J. W. Penno. 1999. Validation of body condition scoring by using ultrasound measurements of subcutaneous fat. Proc. N.Z. Soc. Anim. Prod. 59:177-179.

McNeill, R. E., M. G. Diskin, J. M. Sreenan, and D. G. Morris. 2006. Associations between milk progesterone concentration on different days and with embryo survival during the early luteal phase in dairy cows. Theriogenology 65:1435-1441.

McNeilly, A. S. 2001. Lactational control of reproduction. Reprod. Fertil. Dev. 13:583-590.

Mitchell, M. D., C. C. Osepchook, K. C. Leung, C. D. McMahon, and J. J. Bass. 2006. Myostatin is a human placental product that regulates glucose uptake. J. Clin. Endocrinol. Metab. 91:14341437.

Nicholas, B., R. Alberio, A. A. Fouladi-Nashta, and R. Webb. 2005. Relationship between low-molecular-weight insulin-like growth factor-binding proteins, caspase-3 activity, and oocyte quality. Biol. Reprod. 72:796-804.

National Research Council. 2001. Nutrient Requirements of Dairy Cattle. Natl. Acad. Press, Washington, DC.

Okamura, H., and S. Ohkura. 2007. Neuroendocrine control of reproductive function in ruminants. Anim. Sci. J. 78:105-111.

Pfaff, D. 2005. Hormone-driven mechanisms in the central nervous system facilitate the analysis of mammalian behaviours. J. Endocrinol. 184:447-453.

Philipsson, J., and B. Lindé. 2003. Experiences of including reproduction and health traits in Scandinavian dairy cattle breeding programmes. Livest. Prod. Sci. 83:99-112.

Rae, M. T., S. Palassio, C. E. Kyle, A. N. Brooks, R. G. Lea, D. W. Miller, and S. M. Rhind. 2001. Effect of maternal undernutrition during pregnancy on early ovarian development and subsequent follicular development in sheep fetuses. Reproduction 122:915922.

Rawson, J. A., C. J. Scott, A. Pereira, A. Jakubowska, and I. J. Clarke. 2001. Noradrenergic projections from the A1 field to the preoptic area in the brain of the ewe and Fos responses to oestrogen in the A1 cells. J. Neuroendocr. 13:129-138.

Rhind, S. M., D. A. Elston, J. R. Jones, J. R. Rees, S. R. McMillen, and R. G. Gunn. 1998. Effects of restriction of growth and development of Brecon Cheviot ewe lambs on subsequent lifetime reproductive performance. Small Rumin. Res. 30:121-126.

Rhodes, F. M., L. M. Chagas, B. A. Clark, and G. A. Verkerk. 2003. Effect of dietary intake on steroid feedback on release of luteinizing hormone in ovariectomized cows. Reprod. Fertil. Dev. 15:11-17.

Roche, J. F. 2006. The effect of nutritional management of the dairy cow on reproductive efficiency. Anim. Reprod. Sci. 96:282-296.

Roche, J. R., D. P. Berry, and E. S. Kolver. 2006. Holstein-Friesian strain and feed effects on milk production, body weight, and body condition score profiles in grazing dairy cows. J. Dairy Sci. 89:3532-3543.

Roche, J. R., P. G. Dillon, C. R. Stockdale, L. H. Baumgard, and M. J. VanBaale. 2004. Relationships among international body condition scoring systems. J. Dairy Sci. 87:3076-3079.

Roche, J. R., K. A. Macdonald, C. R. Burke, J. M. Lee, and D. P. Berry. 2007. Associations among body condition score, body weight and reproductive performance in seasonal-calving dairy cattle. J. Dairy Sci. 90:376-391.
Royal, M. D., A. O. Darwash, A. P. F. Flint, R. Webb, J. A. Woolliams, and G. E. Lamming. 2000. Declining fertility in dairy cattle: Changes in traditional and endocrine parameters of fertility. Anim. Sci. 70:487-501.

Royal, M. D., J. E. Pryce, J. A. Woolliams, and A. P. F. Flint. 2002. The genetic relationship between commencement of luteal activity and calving interval, body condition score, production and linear type traits in Holstein-Friesian dairy cattle. J. Dairy Sci. 85:3071-3080.

Sinclair, K. D., M. Kuran, F. E. Gebbie, R. Webb, and T. G. McEvoy. 2000. Nitrogen metabolism and fertility in cattle: II. Development of oocytes recovered from heifers offered diets differing in their rate of nitrogen release in the rumen. J. Anim. Sci. 78:2670-2680.

Sinclair, K. D., and R. Webb. 2005 Fertility in the modern dairy heifer. Pages 277-306 in Calf and Heifer Rearing. P.C. Garnsworthy, ed. Nottingham University Press, Nottingham, UK.

Sotiropoulos, A., M. Ohanna, C. Kedzia, R. K. Menon, J. J. Kopchick, P. A. Kelly, and M. Pende. 2006. Growth hormone promotes skeletal muscle cell fusion independent of insulin-like growth factor 1 up-regulation. Proc. Natl. Acad. Sci. USA 103:7315-7320.

Spicer, L. J., and C. C. Francisco. 1998. Adipose obese gene product, leptin, inhibits bovine ovarian thecal cell steroidogenesis. Biol. Reprod. 58:207-212.

Spicer, L. J., J. L. Voge, and D. T. Allen. 2004. Insulin-like growth factor-II stimulates steroidogenesis in cultured bovine thecal cells. Mol. Cell. Endocrinol. 227:1-7.

Staples, C. R., J. M. Burke, and W. W. Thatcher. 1998. Influence of supplemental fats on reproductive tissues and performance of lactating cows. J. Dairy Sci. 81:856-871.

Strassman, G., L. F. Liang, and S. Toupouzis. 2002. Methods for treating diabetes. US Patent 20020031517. Metamorphix Inc., assignee.

Tena-Sempere, M. 2005. Exploring the role of ghrelin as novel regulator of gonadal function. Growth Horm. IGF Res. 15:83-88.

Underwood, E. J., and N. F. Suttle. 2001. The Mineral Nutrition of Livestock. CABI Publ., New York, NY.

Wade, G. N., and J. E. Jones. 2004. Neuroendocrinology of nutritional infertility. Am. J. Physiol. Regul. Integr. Comp. Physiol. 287:R1277-R1296.

Waltner, S. S., J. P. McNamara, and J. K. Hillers. 1993. Relationships of body condition score to production variables in high producing Holstein dairy cattle. J. Dairy Sci. 76:3410-3419.

Watson, A. J., M. E. Westhusin, and Q. A. Winger. 1999. IGF paracrine and autocrine interactions between conceptus and oviduct. J. Reprod. Fertil. Suppl. 54:303-315.

Webb, R., P. C. Garnsworthy, J. G. Gong, and D. G. Armstrong. 2004 Control of follicular growth: Local interactions and nutritional influences. J. Anim. Sci. 82(E Suppl.):E63-E74.

Webb, R., B. Nicholas, J. G. Gong, B. K. Campbell, C. G. Gutierrez, H. A. Garverick, and D. G. Armstrong. 2003. Mechanisms regulating follicular development and selection of the dominant follicle. Reprod. Suppl. 61:71-90.

Wiltbank, M., H. Lopez, R. Sartori, S. Sangsritavong, and A. Gumen. 2006. Changes in reproductive physiology of lactating dairy cows due to elevated steroid metabolism. Theriogenology 65:17-29.

Wright, I. A., and A. J. F. Russel. 1984. Partition of fat, body composition and body condition score in mature cows. Anim. Prod. 38:23-32.

Wynne, K., S. Stanley, B. McGowan, and S. Bloom. 2005. Appetite control. J. Endocrinol. 184:291-318.

Zieba, D. A., M. Amstalden, and G. L. Williams. 2005. Regulatory roles of leptin in reproduction and metabolism: A comparative review. Domest. Anim. Endocrinol. 29:166-185.

Zimmers, T. A., M. V. Davies, L. G. Koniaris, P. Haynes, A. F. Esquela, K. N. Tomkinson, A. C. McPherron, N. M. Wolfman, and S. J. Lee. 2002. Induction of cachexia in mice by systemically administered myostatin. Science 296:1486-1488. 